\title{
Good teacher perceptions of students attending the pedagogical formation certificate program
}

\author{
Zeynep Ayvaz-Tuncel, İbrahim Tuncel
}

Department of Educational Science, Pamukkale University, Turkey

\begin{tabular}{|c|c|}
\hline Article Info & ABSTRACT \\
\hline Article history: & \multirow{9}{*}{$\begin{array}{l}\text { A pedagogical formation certificate is required to become a teacher in } \\
\text { secondary schools in Turkey. This certificate program, which is required to } \\
\text { obtain in addition to a bachelor's degree from any faculty other than the } \\
\text { education faculties, aims at providing the knowledge, capabilities and } \\
\text { attitudes required by the profession of teaching. This study aims at } \\
\text { determining the perceptions of prospective teachers attending the } \\
\text { pedagogical formation program about the properties of a good teacher. Data } \\
\text { were collected using a survey comprising an open-ended question and } \\
\text { content analysis was conducted to obtain the themes in this study, which } \\
\text { adopted a descriptive method. Based on the properties of a good teacher, } \\
\text { expressed by the prospective teachers, the themes "personal characteristics", } \\
\text { "enforcement of teaching process", "establishing a democratic classroom } \\
\text { environment" and "assessment and evaluation" are obtained. }\end{array}$} \\
\hline Received Dec 10, 2018 & \\
\hline Revised Feb 12, 2019 & \\
\hline Accepted Feb 20, 2019 & \\
\hline Keywords: & \\
\hline Certificates program & \\
\hline Good teacher perception & \\
\hline Pedagogical formation & \\
\hline Prospective teacher & \\
\hline
\end{tabular}

Copyright (C) 2019 Institute of Advanced Engineering and Science. All rights reserved.

\section{Corresponding Author:}

Zeynep Ayvaz-Tuncel

Department of Education Science, Pamukkale University, Kınıklı Kampusu, 20100, Denizli, Turkey.

Email: zayvaztuncel@gmail.com

\section{INTRODUCTION}

Different practices have been tried in the teacher training process in Turkey since the first years of the Republic. Secondary education teacher training, too, has become an area where numerous practices have been implemented. The teacher training process, which has started with education institutes, higher teacher training schools and universities, was left to universities as of 1982. However, the practices referred to with many different names have been tried and changed in the pursuit of the best practices. In years, teaching profession courses were given in faculties other than education faculties during graduate education, after the completion of the field knowledge courses or as a non-thesis master's program. Since 2014, the "Pedagogical Formation Certificate Program" has been implemented for training the students receiving education from the relevant departments of the universities as secondary school teachers.

The pedagogical formation certificate program is organized to cover two semesters. Table 1 lists the courses to be taken under this program. As it is seen in Table 1, the students participating in the pedagogical formation certificate program are expected to take 8 compulsory courses, including the Teaching Practice, and two elective courses. The students are entitled to receive the certificate after completing 25 credits, 20 hours theoretical and 10 hours practical courses. The elective courses are also determined with regard to developing the professional knowledge and capacity. 


\begin{tabular}{|c|c|c|c|}
\hline Semester I & T-P-C & Semester II & T-P-C \\
\hline Introduction to Pedagogy & 202 & Special Teaching Methods & 223 \\
\hline Teaching Principles and Methods & 202 & Teaching Tech. and Material Design & 223 \\
\hline Assessment and Evaluation in Education & 202 & Teaching Practice & 265 \\
\hline Educational Psychology & 202 & Elective II & 202 \\
\hline Class Management & 202 & & \\
\hline Elective I & 202 & & \\
\hline
\end{tabular}

Many different practices for training teacher for secondary education unfortunately could not solve the quality problems of teacher training. Because, the main problem arises from the inability to attain the quality in the implementation process of the program and its variable, rather than the name of the program. Many studies have been conducted on the issue and the problems have been revealed. However, the practices towards the solution of the problems and increasing the quality of the teachers trained could not be carried out.

Memduhoğlu and Topsakal [2] argue, in their study on the formation program, that there are problems in the courses arising from the instructors, and the delivery of the courses related to teaching profession by instructors, who are not pedagogy specialists, reduced the efficiency and benefits of the courses. Similarly, Gündoğdu, Çoban and Ağırbaş [3] show that the peers in the formation program think that the instructors delivering the courses are not competent with regard to field knowledge and transferring capabilities. Yapıc1 and Yapıc1 [4], in their metaphor study on the formation program, found that the students generally formed negative metaphors and this situation originated from negative emotions and opinions about the profession and the instructors giving the training. Y1lmaz [5] argued that the pedagogical formation training was seen as an inadequate and unproductive practice by the students, administrators and instructors, and they were not satisfied by the way the program had been carried out. Çiçek Sağlam's [6] study, too, reveals the incompetency of the instructors. Based on all the aforementioned studies, it is seen that the problems in the implementation of the formation program have continued for years, and the quality of the instructors has been influential in the origins of these problems. Although the current secondary education teacher training system has reached to a standard in the quantitative data as the number of the courses to be taken, the time to be spent in teaching practice sessions; it can be argued that it has not attained a certain standard with regard to the qualities of the teaching environments, the teaching-learning processes, and the quality of instructors and practice teachers.

To raise critical and independent thinking, self-confident, problem solving, self-controlled, freewilled individuals with a developed sense of responsibility, a sound mind who are productive and innovative, the teachers themselves should have these characteristics [7]. The perspective of teachers on teaching profession, the teacher characteristics they have and their attitudes towards the profession have direct impact on the quality of education and the characteristics of the individual raised. However, it was found in a study conducted by Yalçın [8] that the students whose achievement level is low or moderate were affected by teacher characteristics/behaviours more.

The individuals form a perception of teaching profession since their early ages through their families, close environment, media and the educational institutions. It is possible to mention the effects of both curricula, hidden and official, on the formation of the perception about the "good teacher characteristics". The influence of the behaviors and attitudes of the teachers the students have encountered in their learning experiences could be called the hidden curriculum. The latter, the official program, is the "good teacher perception" formed with the outcomes of the theoretical and practical courses in the students who attend the "Pedagogical Formation Certificate Program". The teachers, that the individual has interacted with, plays an important role in the formation of this perception. Individuals, who have not interacted with teachers having ideal characteristics and thus could not find the opportunity to take a correct role model, would exhibit unwanted behavior in their teaching experiences. The pedagogical formation certificate program has a key role in attaining the desirable behaviors by the prospective teachers to be assigned in secondary education. It can be argued that the content of the courses to be attended during the program, the characteristics of the instructors responsible for the courses, the attitudes and behaviors of the practice teachers and the administrators are influential in the formation of the teacher perception of the prospective teachers. The "good teacher perception" of the prospective teachers is also a sign of how a teacher they would become. Therefore, revealing the teacher perceptions is considered significant with regard to increasing the quality of teacher training programs. This study aimed at determining the good teacher perceptions of prospective teachers attending the pedagogical formation certificate program.

Int. J. Eval. \& Res. Educ. Vol. 8, No. 1, March 2019: 165 - 172 


\section{RESEARCH METHOD}

This research is a descriptive study towards revealing the teacher perception prospective teachers have and determining whether the formation certificate program they attend changed this perception. The study was conducted with the students participating in a pedagogical formation certificate program carried out in 2017-2018 academic year in a state university. 165 prospective teachers, determined via convenient sampling, participated in the pre-implementation of the study at the beginning of the certificate program, and they used aliases to define themselves. At the end of the certificate program, 122 prospective teachers answered the post-implementation, again with aliases. However, only the answers of 44 of the prospective teachers among the participants of the pre- and the post-implementation, whose aliases match were included in the study. All of the prospective teachers in the study group were either senior students or graduates of various departments in the Faculty of Sciences and Letters. To collect data, a survey was used comprising of an open-ended question in order the participants could reflect their opinions without limiting themselves. The question, formed in accordance with expert views, was tried with five prospective teachers and the final form of the survey was given. The question in the survey is "Explain the characteristics a good teacher should have".

The answers given to the question in the survey were organized in computer environment and the data set was formed, and a content analysis was conducted. Codings were done on the data, the themes were determined, the coding-theme correspondences were reviewed and their frequencies were calculated. A report was prepared by giving quotations from the answers.

A data collection tool was organized in this study, considering the research question, the data were transferred to the computer environment without alterations, the data set was coded by two independent researchers and the confidence coefficient was found $92 \%$. The findings were described by including quotations and the written documents, codings and all other reports and analyses were stored to be submitted for verification if required.

\section{FINDINGS}

Using the codes obtained at the end of the content analysis of the data about good teacher perception obtained from prospective teachers both at the beginning and at the end of the formation program, the themes "personal characteristics", "enforcement of teaching process", "establishing a democratic classroom environment" and "assessment and evaluation" were determined. Table 2 reveals the theme-personal characteristics.

Table 2. Theme - personal characteristics

\begin{tabular}{lclc}
\hline At the beginning of the program & $\mathrm{f}$ & At the end of the program & $\mathrm{f}$ \\
\hline Efficient communication & 37 & Efficient Communication & 41 \\
Endearing oneself to the students & 33 & Appreciating the student & 36 \\
Loving the profession & 30 & Loving the profession & 34 \\
Being good humored & 24 & Being a model & 26 \\
Being open to improving oneself and innovation & 18 & Being non-oppressive & 24 \\
Being contentious & & Being open to improving oneself and innovation & 20 \\
Being reliable & 17 & Being good humored & \\
Being a model & 18 & Being tolerant & 18 \\
Being authoritarian & 15 & Being open to criticism & 17 \\
Being Patient & 11 & Endearing oneself to the students & 15 \\
Being self-confident & 7 & Being patient & 11 \\
Being fair & 5 & & 9 \\
& 7 & & \\
\hline
\end{tabular}

When the data are analyzed, it is found that the prospective teachers expressed 12 personal characteristics of a good teacher at the beginning of the program, while they expressed 11 personal characteristics at the end. The characteristics "effective communication, loving the profession, being good humored, being a model, being open to improving oneself and innovation, endearing oneself to the students, and being patient" emerge as good teacher characteristics both at the beginning and at the end of the program. While the characteristics "being contentious, being reliable, being authoritarian, being selfconfident and being fair" were attributed to a good teacher at the beginning of the program, it is seen that these characteristics were changed to "being non-oppressive, being tolerant, and being open to criticism" at the end of the program.

While the most emphasized personal characteristic at the beginning of the program was "effective communication ( $\mathrm{f}=37)$ ", the most emphasized at the end was again "effective communication ( $\mathrm{f}=41)$ ". At the beginning of the program, the prospective teacher ID stated, "A good teacher could use their body language

Good teacher perceptions of students attending the pedagogical formation... (Zeynep Ayvaz-Tuncel) 
and voice efficiently. They could teach them by establishing eye contact"; at the end the same prospective teacher ID wrote, "In my opinion, a good teacher is the one who could establish communication with the students in the most efficient way. Because, communication is of great importance in training a person or in teaching something to that person. The communication skills of a teacher are also influential in their way of teaching.", and preserved his/her opinion that a good teacher is the one who could establish an efficient communication. When the data are examined, it is seen that "effective communication" was emphasized as a good teacher characteristics by almost all prospective teachers both at the beginning and at the end of the program.

While the second most emphasized personal characteristic at the beginning of the program was "endearing oneself to the students $(\mathrm{f}=33)$ ", the second most emphasized characteristic became "appreciating the student ( $\mathrm{f}=36)$ " at the end of the study. It is seen, in this finding that, the perception of endearing of the teacher to the students transformed into appreciating the student at the end of the program. Accordingly, it is remarkable that while the prospective teacher HT stated, at the beginning of the program, "If the student loves the teacher, they would be more interested in the lesson. If they had a negative feeling about the teacher, their interest would decrease. Therefore, a good teacher must endear themselves to the students."; the same prospective teacher HT wrote "A good teacher must not disincline a student from the lesson, they must not use words or show behavior insulting the student while delivering the lesson. This finding can be interpreted as a transition from the egocentric attitude of the teacher towards a perspective, which places the student in the center.

Both at the beginning $(\mathrm{f}=30)$ and at the end $(\mathrm{f}=34)$ of the program, the characteristic "loving the profession" was perceived as a good teacher characteristics by prospective teachers. While the prospective teacher ZC declared "A teacher should first love the job they do and thus they imbue the students with this love. A student understands very well the mood of a teacher...if they do not deliver the lesson with love, the student would not love that lesson..."; the same prospective teacher ZC emphasized that their opinions about loving the profession had not changed by writing "After all these formation courses, I understood, once again, that people who love this profession should become teachers. People working other jobs say, "I am going to work" when they leave in the morning. However, the teachers say they are going to "school". In other words, they do not see this as a job, since being a teacher needs loving it." When the data are examined, it is determined that there are opinions stating that loving the profession is valid for all professions, but this has a particular importance in teaching profession.

While the characteristic "being a model $(\mathrm{f}=15)$ " was expressed less frequently at the beginning of the program, it was found that "being a model $(\mathrm{f}=26)$ " became a more frequently expressed good teacher characteristics at the end of the program. The prospective teacher EO stated, "A teacher should be a model to the students with their communication and behavior." and expresses their opinion as "A teacher is the one who should become a model with their behavior. Teachers are defined as models in our society." It is seen that while the characteristic "being good humored $(\mathrm{f}=24)$ " was more frequently expressed at the beginning of the program, the characteristic "being a model" was more frequently expressed at the end of the program.

It is found that the characteristics "being authoritarian $(\mathrm{f}=11)$ " determined at the beginning of the program was not present at the end of the program, and instead the characteristics "being non-oppressive $(\mathrm{f}=24)$ " and "being tolerant $(\mathrm{f}=17)$ " were emphasized. While "being open to criticism" was not defined as good teacher characteristic at the beginning of the program, it is remarkable finding that it appeared as a good teacher characteristic at the end of the program.

Table 3. Theme - enforcement of teaching process

\begin{tabular}{lclc}
\hline At the beginning of the program & f & At the end of the program & $\mathrm{f}$ \\
\hline Field Knowledge & 39 & Enabling active participation & 36 \\
Motivating the student for the lesson & 32 & Motivating the student for the lesson & 35 \\
Taking individual differences into consideration & 21 & Taking individual differences into consideration & 33 \\
Using teaching technologies & & Effective planning & 32 \\
Being a guide & 17 & Using teaching technologies & 31 \\
Developing thinking skills & 12 & Using different methods and techniques & 29 \\
Prioritizing students' interests and needs & 11 & Enabling meaningful learning & 22 \\
& 4 & Developing thinking skills & 21 \\
& & Being guide & 20 \\
& & Field Knowledge & 17 \\
& & Class Management & 15 \\
& & Prioritizing students' interests and needs & 5 \\
& & Directing to different resources & 3 \\
\hline
\end{tabular}

Int. J. Eval. \& Res. Educ. Vol. 8, No. 1, March 2019: 165 - 172 
At the end of the analysis of the data, seven codes were obtained in the "Enforcement of Teaching Process" theme at the beginning of the program and 13 codes were obtained at the end. When the codes obtained are examined, it is seen that the codes appearing at the end of the program, such as "enabling active participation, using different methods and techniques, enabling meaningful learning, class management, and directing to different resources" were not present at the beginning of the program. While "field knowledge $(\mathrm{f}=39$ )" was emphasized the most at the beginning, it is found that the "enabling active participation ( $\mathrm{f}=36)$ " was emphasized more at the end. On the other hand, while "being a guide $(\mathrm{f}=12)$ " was expressed less frequently at the beginning, it was expressed more frequently than "field knowledge $(\mathrm{f}=17)$. This finding shows that the characteristics "enabling meaningful learning, developing thinking skills and being a guide" were prioritized at the end of the program instead of "field knowledge".

At the beginning of the program, the prospective teacher SH stated, "In my opinion, a teacher should be successful in their field and transfer their knowledge to the students.", while the same SH wrote "a good teacher should make the students more active and enable participation in the lesson, instead of transferring knowledge to the students." at the end of the program. It is remarkable for showing the effect of the program that NS, one of the prospective teachers wrote, "a good teacher should get a hold of their lessons and have a high explaining and understanding capacity." at the beginning while the same prospective teacher NS wrote "instead of a rote-learning education, a teacher who teaches in a way that the students could internalize and reason, and raises students who could relate the theoretical knowledge with practice, is a good teacher."

"Motivating the student for the lesson" was found as a frequently expressed good teacher characteristic by the students both at the beginning $(\mathrm{f}=32)$ and at the end $(\mathrm{f}=35)$ of the program. At the beginning, ME wrote, "the student should learn the lesson willingly and voluntarily instead of an anxiety of getting a low grade. Entertaining examples that they could relate with real life should be given in the lessons." and stated, "when providing the students with information, the students should also be explained that this information would be useful in this or that areas and it should be related to life."

It is found that "taking individual differences" was perceived as a good teacher characteristic both at the beginning $(\mathrm{f}=21)$ and at the end $(\mathrm{f}=33)$ of the program; however, it was expressed more frequently at the end of the study. The statement of SB, one of the prospective teachers stated at the beginning as "There are an average of 30 students before them while giving a lesson. This means 30 different individuals. One of them is an introvert, another does not like participating in the lesson, yet another restless; the teachers should be aware of these and if they do not miss any of these, they are good teachers.", and the statement of NC at the end of the program as "The teacher should follow a program not for themselves but for the students in the classroom." show that taking individual differences into consideration is acknowledged as a good teacher characteristic.

While any data could not be obtained about "effective planning" in the beginning, it was found that "effective planning $(\mathrm{f}=32)$ " was expressed as a good teacher characteristic by most of the students at the end of the program. The statement by one prospective teacher TB as "A teacher should first be prepared for the lesson. Because, there may be many things that could go unnoticed and could not be remembered. A plan should be made about the lesson and this plan should be followed, and the time should be used accordingly and efficiently." and the statement by AT as "Previously, I thought differently about the concept of teaching, now I think differently after receiving the formation program. In my opinion, being a teacher is not coming to class and reading and explaining; but it is certainly having a good plan and knowing well the teaching methods and techniques." are remarkable for revealing the change in good teacher perception at the end of the program.

Table 4. Theme - establishing a democratic classroom environment

\begin{tabular}{lclc}
\hline At the beginning of the program & $\mathrm{f}$ & At the end of the program & $\mathrm{f}$ \\
\hline Respecting differences & 25 & Respecting differences & 28 \\
Being unprejudiced towards students & 16 & Being unprejudiced towards students & 16 \\
\hline
\end{tabular}

At the end of the analysis of the data, the codes "respecting differences" and "being unprejudiced towards students" were obtained and gathered under the theme "establishing a democratic classroom environment". It was found that "respecting differences" was perceived as a good teacher characteristic both at the beginning $(\mathrm{f}=25)$ and at the end $(\mathrm{f}=28)$ of the program. The opinion of the prospective teacher EB as "A segregation with regard to religion, language, race and sect should not be made, because one should be aware that individual characteristics are more important and never forget this." and the statement by ZK "The people should be approached without marginalizing them, without condemning them for their thoughts or living." emphasize that respecting differences is perceived as a good teacher characteristic. In addition, it was found that the "being unprejudiced towards students" characteristic was expressed by the same prospective

Good teacher perceptions of students attending the pedagogical formation... (Zeynep Ayvaz-Tuncel) 
teachers at the beginning and at the end of the program. SE commented on this topic as "They should not be prejudiced towards the students and they should disincline students from the lesson."; AS stated, "a good teacher should be open to all views and should not have prejudice"; and NY stated, "a good teacher, in my opinion, should approach the student unbiased and should treat all students equally as possible."

Table 5. Theme - assessment and evaluation

\begin{tabular}{lclc}
\hline At the beginning of the program & f & At the end of the program & $\mathrm{f}$ \\
\hline Being fair/objective & 33 & Being objective & 35 \\
& & $\begin{array}{l}\text { Using alternative assessment and evaluation approaches } \\
\text { Holding responsible for what was taught }\end{array}$ & 19 \\
& & & 12 \\
\hline
\end{tabular}

With regard to assessment and evaluation, "being objective $(\mathrm{f}=33)$ " both at the beginning $(\mathrm{f}=33)$ and at the end $(\mathrm{f}=35)$ of the program was found as a good teacher characteristic perceived by prospective teachers. ZK, one of the prospective teachers expressed their opinion as "being able to make a fair and righteous evaluation without giving rise to unjust grading or backing, to which most of us had been exposed in the past, should be one of the characteristics a teacher has." When the opinions of the prospective teachers are examined, it is found that "being objective" is the most frequently emphasized good teacher characteristic related to assessment and evaluation.

While "using alternative assessment and devaluation approaches ( $\mathrm{f}=19)$ " was not expressed at the beginning of the program, it is found at the end of the program. A comment by one of the prospective teacher RY shows that there is a search for an alternative in evaluation as "I am against all kinds of written exams. Always the same assessment instruments are being used. I don't think anymore that a student's knowledge could be assessed with these exams. Project should be prepared and researches should be conducted by the students and in my opinion, a good teacher should be able to reveal in different ways whether the student has learnt." Another prospective teacher CC expressed their opinions as "the aim should not be to measure whether each student reached the same level using the well-known assessment instruments; a teacher should be able to make an evaluation towards assessing the effort of each student."

"Holding responsible for what was thought $(\mathrm{f}=9)$ ") is a good teacher characteristic that was expressed at the end of the program. The statement by one prospective teacher BE "If I would make an exam, first I would look into coherence, which subjects are contained and what have the students learnt, I would look into this. I would not ask about the things I haven't taught." and the comments of ÖF as "questions other than the subjects taught should not be asked and more importantly the students should not be thrown a curve." are remarkable.

\section{DISCUSSION}

The experiences of prospective teachers during their primary, secondary and higher education cause the formation of a perspective on what characteristics a teacher should have. The formation certificate program, which is expected to form knowledge, skills and attitudes related to teaching profession, is also expected to bring in the efficient teacher characteristics. At the end of the analysis of the data obtained in this study, the characteristics a teacher should have are grouped under "personal characteristics", "enforcement of teaching process", "establishing a democratic classroom environment" and "assessment and evaluation" themes.

Based on the analysis of the data, it is found that that there is not any change in the characteristics of effective communications, loving the profession, being good humored, being a model, being open to improving oneself and innovation, endearing oneself to students, and being patient. However, although they were not expressed at the beginning of the program, it is found that the characteristics of being nonoppressive, being tolerant and being open to criticism have started to be perceived as good teacher characteristics, and the program has a contribution in forming this perception. With regard to personal characteristics, while endearing the teacher to students was expressed as a good teacher characteristic at the beginning, this changed to appreciating the student at the end of the program. It can be argued that the reason for this change was the emphasis on the student-centered approaches in the courses. Çeliköz and Çetin [9], Karakelle [10] and Özkan and Arslantaş [11] found that effective communication, loving the profession, being open to improvement should be present in an effective teaching.

When the codes under the "enforcement of teaching process" are examined, it is seen that the codes "enabling active participation, using different methods and techniques, effective planning, enabling meaningful learning, class management, directing to different resources" were not emphasized at the

Int. J. Eval. \& Res. Educ. Vol. 8, No. 1, March 2019: 165 - 172 
beginning of the program. In addition, it is remarkable that although having field knowledge was perceived as a good teacher characteristic at the beginning of the program, the characteristics of enabling active participation and being a guide were emphasized more at the end. This shows that the formation program is effective in raising awareness of the importance of organizing processes which are student-centered and which support meaningful learning. It is also emphasized in the literature that having a high-level field knowledge is not sufficient in enforcing the process [12], [13]. Darling-Hammond [14] argues that using a wide-spectrum of teaching methods for enforcing the teaching process is one of the characteristics of a qualified teacher. Similarly, Çetin [15] states that an ideal teacher should have the skills to enrich the subject and render it more learnable for the students. The courses provided in the pedagogical formation programs should be enriched with anecdotes about real classroom experiences and case studies, in addition to the theory. The instructors should focus on case study use and experience sharing as a teaching method when planning their courses [16].

At the end of the data analysis, the codes "respecting differences" and "being unprejudiced towards students" were obtained and grouped under the theme "establishing a democratic classroom environment". Due to obtaining the same codes at the beginning and at the end of the program, and due to lack of change in the frequencies, it was concluded that there was not any change in the perceptions of the prospective teachers. However, when the quotations are considered, it was found that the prospective teachers perceived this as a good teacher characteristic due to their learning experiences in non-democratic classroom environments. According to Field and Field [17], ideal and efficient teachers should be aware of the differences of their students and have the capacity to take the required measures. As Ilgar [18] asserts, the teachers should have a more democratic and egalitarian discipline attitude rather than a harsh discipline approach.

While the prospective teachers perceived only "being objective" as a good teacher characteristic related to assessment and evaluation at the beginning, it is seen that they emphasized, in addition to this characteristics, the ability to make alternative evaluation and holding responsible for what was taught characteristics. It could be argued that this enrichment in their perspective about assessment and evaluation arise from the courses taken in the formation program and the experiences had.

When the good teacher perceptions of the prospective teachers are compared in general, it is concluded that the Pedagogical Formation Certificate Program was more influential in their perceptions about the role of the teacher in the teaching process and assessment and evaluation rather than their perceptions about personal characteristics and establishing a democratic classroom environment. Ocak and Gündüz [19] concluded that the prospective teachers had different perceptions about the teaching profession before and after the course "Introduction to Teaching Profession". However, Başbay, Ünver and Bümen's [20] study found that the secondary education teacher training process could not contribute to a positive change in the attitudes of the students towards teaching profession.

\section{CONCLUSION}

When it is considered that the "good teacher perceptions" of the prospective teacher was not formed in a purposeful or deliberate manner at the beginning of the program, it can be argued that these perceptions were formed with the hidden curriculum. When the codes, emerged at the beginning and at the end of the program, were analyzed in comparison, the change in the codes under the themes "personal characteristics" and "establishing a democratic classroom environment" seemed less, while there were more changes in the codes under the "enforcement of teaching process" and "assessment and evaluation". Put it differently, it is concluded that the influence of the program on the good teacher perceptions is more prominent in the perceptions related to "enforcement of teaching process" and "assessment and evaluation". In this context, it can be argued that the influence of the hidden curriculum is more prominent on the themes "personal characteristics" of a good teacher and "establishing a democratic classroom environment", and the influence of the official curriculum, i.e. the pedagogical formation certificate program, is more prominent in the themes "enforcement of teaching process" and "assessment and evaluation".

It was difficult to reveal the reasons for the change or lack of change in the perception of the prospective teachers since the data were collected in written form. Not using different data collection tools is an important limitation of the study. With further studies, conducted with different data collection tools, the factors influencing the formation of good teacher perceptions could be investigated.

\section{ACKNOWLEDGEMENTS}

This study was presented as an oral presentation at the 6th International Congress on Curriculum and Instruction at Kafkas University held 11-13 October 2018, Kars, Turkey. 


\section{REFERENCES}

[1] Yüksek Öğretim Kurulu (YÖK), "Pedagojik formasyon eğitimi sertifika programına ilişkin usul ve esaslar," Ankara, 2014.

[2] Memduhoğlu, H. B. and Topsakal, C., "Öğrenci ve öğretim elemanlarının görüşlerine göre ortaöğretim Alan öğretmenliğinin tezsiz yüksek lisans programlarının niteliği ve programlarda yaşanan sorunlar," Ege Eğitim Dergisi, vol. 9(1), pp. 95-129, 2008.

[3] Gündoğdu, C., Çoban, B. and Ağirbaş, Ö, "The opinions of teachers and teacher candidates of physical education and sports about the sufficiency of formation courses," Erzincan Üniversitesi Eğitim Fakültesi Dergisi, vol. 12(2), pp. 97-114, 2012.

[4] Yapıc1, M. and Yapıcı, Ş., "Öğretmen adaylarının pedagojik formasyona ilişkin metaforları," Turkish Studies, vol. 8(8), pp. 1421-1429, 2013.

[5] Yılmaz, G., "Pedagojik formasyon yoluyla öğretmen yetiştirme uygulamalarında karşıllaşılan güçlükler ve mezunların istihdamlarının değerlendirilmesi," Unpublished Master Thesis, Fırat Üniversitesi, Eğitim Bilimleri Enstitüsü, Elazı ğ, 2015.

[6] Çiçek Sağlam, A., "Pedagojik formasyon sertifika programının etkililiğinin öğrenci görüşlerine göre değerlendirilmesi," Kırlkkale Üniversitesi Sosyal Bilimler Dergisi, vol. 5(2), pp. 63-73, 2015.

[7] Açıkgöz, K., "Aktif Öğrenme", Eğitim Dünyası Yayınları, İzmir, 2003.

[8] Yalçın, S., "Teacher behaviours explaining Turkish and Dutch students' mathematic achievements," International Journal of Evaluation and Research in Education (IJERE), vol. 6(2), pp.174-182, 2017.

[9] Çeliköz, N. and Çetin, F., "Anadolu öğretmen lisesi öğrencilerinin öğretmenlik mesleğine yönelik tutumlarını etkileyen etmenler," Milli Ĕ̈itim Dergisi, vol. 162(1), pp. 139-157, 2004.

[10] Karakelle, S., "Öğretmenlerin etkili öğretmen tanımlarının etkili öğretmenlik boyutlarına göre incelenmesi," Eğitim ve Bilim, vol. 30(135), 2005.

[11] Özkan, M., and Arslantaş, H. İ., "Etkili öğretmen özellikleri üzerine siralama yöntemiyle bir ölçekleme çalişmasi," Trakya University Journal of Social Science, vol. 15(1), 2013.

[12] Çiltaş, A., and Akıllı, M., "Öğretmenlerin pedagojik yeterlilikleri," Mehmet Akif Ersoy Üniversitesi Sosyal Bilimler Enstitüsü Dergisi, vol. 3(4), pp. 64-72, 2011.

[13] Taneri, P. O., "Öğretmen adaylarinin pedagojik formasyon sertifika programinin niteliği hakkindaki görüşleri (Çankiri ili örneği)," Kastamonu Education Journal, vol. 24(3), pp. 997-1014, 2016.

[14] Darling-Hammond, L., "Teacher quality and student achievement: a review of state policy evidence," Journal of Education Policy Analysis, 8 (1), vol. pp. 6-11, 2000.

[15] Çetin, Ş., "İdeal öğretmen üzerine bir araştırma," Milli Eğitim Dergisi, vol. 149, Ocak, Şubat, Mart 2001.

[16] Dalgıç, G., Doyran, F. and Vatanartıran, S., "Ücretli öğretmenlerin, katıldıkları pedagojik formasyon programına ilişkin deneyimleri," Akdeniz Eğitim Araştırmaları Dergisi, vol. 11, pp. 39-54, 2012.

[17] Field, B., Field, T., et al, "Teachers as Mentors: A Practical Guide," The Falmer Press, London, 1994.

[18] Ilgar, L., "Eğitim Yönetimi, Okul Yönetimi, Sınıf Yönetimi," Beta Yayıncıllk, İstanbul, 2005.

[19] Ocak, G. and Gündüz, M., "Eğitim fakültesini yeni kazanan öğretmen adaylarının öğretmenlik mesleğine giriş dersini almadan önce ve aldıktan sonra öğretmenlik mesleği hakkındaki metaforlarının karşılaştırılması," Afyon Kocatepe Üniversitesi Sosyal Bilimler Dergisi, vol. 8(2), pp. 293-310, 2006.

[20] Başbay, M., Ünver, G., and Bümen, N. T., "Ortaöğretim alan öğretmenliği tezsiz yüksek lisans öğrencilerinin öğretmenlik mesleğine yönelik tutumları: Boylamsal bir çalışma," Kuram ve Uygulamada Eğitim Yönetimi, vol. 59(59), pp. 345-366, 2009.

Int. J. Eval. \& Res. Educ. Vol. 8, No. 1, March 2019: 165 - 172 